\title{
A Frigate in 10 years - Challenges and Opportunities
}

\author{
Una Fragata en 10 años - Desafíos y Oportunidades
}

\begin{abstract}
Colombia is involved in preliminary philosophies regarding the acquisition of frigates in the next 10 years. This presents many challenges as well as opportunities. This not a unique situation as many maritime countries have struggled with this matter over the past 50 years. The question that quickly arises is whether a country should design and construct new naval ships themself or follow one or a combination of the many options that have been used over this period. This presentation will review these options as both challenges and opportunities and hopefully provide a starting point for important discussions of this subject.
\end{abstract}

Key words: naval ship design, naval shipbuilding, required manning level, acquisition options, technology transfer, academic needs, national shipbuilding program

\section{Resumen}

Colombia se encuentra involucrada en filosofías preliminares en cuanto a la adquisición de fragatas en los próximos 10 años. Esto presenta muchos retos, así como oportunidades. Esta no es una situación única, debido a que muchos países marítimos han luchado con este asunto por los últimos 50 ańos. La pregunta que rápidamente surge es si el país debe diseñar y construir nuevas embarcaciones navales por sí mismo o seguir una o una combinación de un número de opciones que han sido utilizadas durante este periodo. Esta presentación revisará estas opciones tanto como retos como oportunidades, y espera brindar un punto de partida para entablar importantes discusiones en este tema.

Palabras claves: diseño de embarcaciones navales, construcción naval, nivel de dotación requerido, opciones de adquisición, transferencia de tecnología, necesidades académicas, programa nacional de construcción naval

Date Received: February 1st, 2013 - Fecha de recepción: 1 de Febrero de 2013

Date Accepted: March 1st, 2013 - Fecha de aceptación: 1 de Marzo de 2013

\footnotetext{
${ }^{1}$ University of Michigan, College of Engineering, Department of Naval Architecture and Marine Engineering. Lynnwood, USA. e-mail: nalamb@umich.edu
} 


\section{Introduction}

Since the end of WWII many maritime countries have faced the task of obtaining new naval ships such as a frigate. In the early time it was often accomplished by buying an existing frigate from one of the larger naval powers such as USA, Britain, Germany, France, Italy and Spain. Others preferred to obtain state of the art new ships from foreign sales naval shipbuilding countries, mainly France and Germany. More recently some maritime countries have decided to get involved in the design and building of their naval ships in a wide range of options as how to achieve this ranging from performing all the work themselves to varying types of partnerships with experienced naval shipbuilding company. Any approach has both challenges and opportunities for the acquiring country and, not surprisingly, there have been both successful and disastrous projects. This paper will use these past approaches, their successes and failures to provide a decision database for continuing discussion of this important factor in obtaining new naval ships today for a country that has had no previous experience in designing and building naval ships and specifically a frigate.

It is recognized that the final decision on which approach to use may be based on factors other than technical and cost such as social and political. Shipbuilding is a labor intensive industry which, for commercial ships, requires a modest financial investment and can be relatively quickly learned. Thus it is a relatively easy industry to join for countries where it can be used to offset unemployment. Japan, Korea and China are all example of this. This presentation will NOT address any of the social or political factors but will focus on the approach technical, cost, and schedule factors.

\section{Setting the stage}

When a maritime country, without a significant current naval ship design and construction capability, decides that it needs to acquire new naval combatant ships they are immediately faced with a number of important decisions: should it be designed from scratch; if so who should design it; if not how to select an existing design; who should modify the design if changes are necessary; and finally who should build the ship(s)? The initial desire is often to design from scratch and by the acquiring country's designers and to build the $\operatorname{ship}(\mathrm{s})$ in their own country. The reason why this is not often done is because the non-existing capability for both design and construction cannot support such a plan from both the cost and time that would be required to do so and even if these are acceptable the risks are great.

A number of countries have faced this problem and have developed a number of approaches to achieve the goal of having the desired naval ships for the desired cost in the desired time frame. These approaches range as follows:

1. purchasing the complete new ship(s) from an experienced foreign naval shipbuilder,

2. purchasing the complete ship(s) based on an existing design from experienced foreign naval shipbuilder,

3. contracting with an experienced foreign naval shipbuilder to either prepare a new design or to select an existing design and for them to build the first ship with the acquiring country building all remaining ships with technical assistance from the selected shipbuilder,

4. purchasing an existing design and technical assistance from a foreign shipbuilder but building all the ships in the acquiring country, and

5. finally, designing from scratch and building in the acquiring country.

Each of these approaches has challenges and opportunities for the acquiring country, and it is the understanding and evaluation of these and the cost and risks involved that is essential to reaching the right decision (compromise). The selected approach may not be one of those listed above but a combination of them. Each case is going to be unique as it depends on many external factors, such as the country's politic goals social and industrial policies and employment goals. 


\section{Current Experience}

Before addressing the challenges and opportunities that the program to build frigates in 10 years offers Colombia or any other similar country, it is useful to look at some of the characteristics of the naval shipbuilding industry around the world. Table I shows the breakdown of recent naval shipbuilding for both export and own use (Birkler et al., 2005). From this it can be seen that the biggest own use countries (USA and Britain) are not significant players in the export of naval ships. Germany, France and Russia dominate this area. Table II shows typical cost (2009) per Lightship ton for a range of naval ships as well as a few commercial ships for comparison.

Table 1. World Naval Shipbuilding. Projected Military Ship Production, 2003-2012

\begin{tabular}{|c|c|c|c|c|c|c|}
\hline & \multicolumn{3}{|c|}{ Export } & \multicolumn{3}{|c|}{ Domestic Use } \\
\hline & Number & $\begin{array}{c}\text { Value } \\
\text { (\$ millions) }\end{array}$ & $\begin{array}{l}\text { LSW } \\
\text { Tons }\end{array}$ & Number & $\begin{array}{c}\text { Value } \\
\text { (\$ millions) }\end{array}$ & $\begin{array}{l}\text { LSW } \\
\text { Tons }\end{array}$ \\
\hline Germany & 56 & 10,713 & 96,040 & 21 & 5,799 & 44,144 \\
\hline France & 25 & 6,405 & 47,570 & 17 & 13,015 & 146,302 \\
\hline Russia & 20 & 5,000 & 36,025 & 0 & 0 & 0 \\
\hline Spain & 6 & 2,035 & 31,343 & 7 & 2,195 & 26,735 \\
\hline The Netherlands & 9 & 1,780 & 8,500 & 4 & 1,585 & 24,759 \\
\hline United Kingdom & 2 & 650 & 3,000 & 22 & 17,340 & 235,140 \\
\hline United States & 2 & 53 & 174 & 66 & 56,172 & 776,446 \\
\hline South Korea & 1 & 30 & 1,500 & 7 & 4,905 & 24,500 \\
\hline Japan & 0 & 0 & 0 & 16 & 11,090 & 79,125 \\
\hline Italy & 0 & 0 & 0 & 18 & 5,289 & 75,170 \\
\hline China & 0 & 0 & 0 & 8 & 3,230 & 26,875 \\
\hline Australia & 0 & 0 & 0 & 1 & 650 & 3,051 \\
\hline Sweden & 0 & 0 & 0 & 3 & 375 & 1,431 \\
\hline Taiwan & 0 & 0 & 0 & 1 & 320 & 2,769 \\
\hline Israel & 0 & 0 & 0 & 11 & 55 & 550 \\
\hline Total & 121 & 26,666 & 224,152 & 202 & 122,020 & $1,446,997$ \\
\hline Not Reported & 23 vessels & led at $\$ 13,22$ & illion and & lacing 8 & 291 tons LSW. & \\
\hline
\end{tabular}

Source: Source: Forecast International Naval Group (2003)

Countries such as Britain, Germany, France and be seen by the demise of the destroyer program Italy, even though they have quite large navies, find the cost of designing new naval ships difficult to justify and have attempted to develop joint designs such as the European Destroyer and the FREM frigate to reduce the cost by sharing resources. That this is not without problems can and Britain opting out of the FREM frigate program (See Fig. 1). This delayed the British Frigate program while the Type 45 Destroyer program was being (Birkler et al., 2005) executed but now work is underway on the Type 26 Frigate for the Royal Navy (see Fig. 2). 
Table 2. Typical Ship Cost (2009)

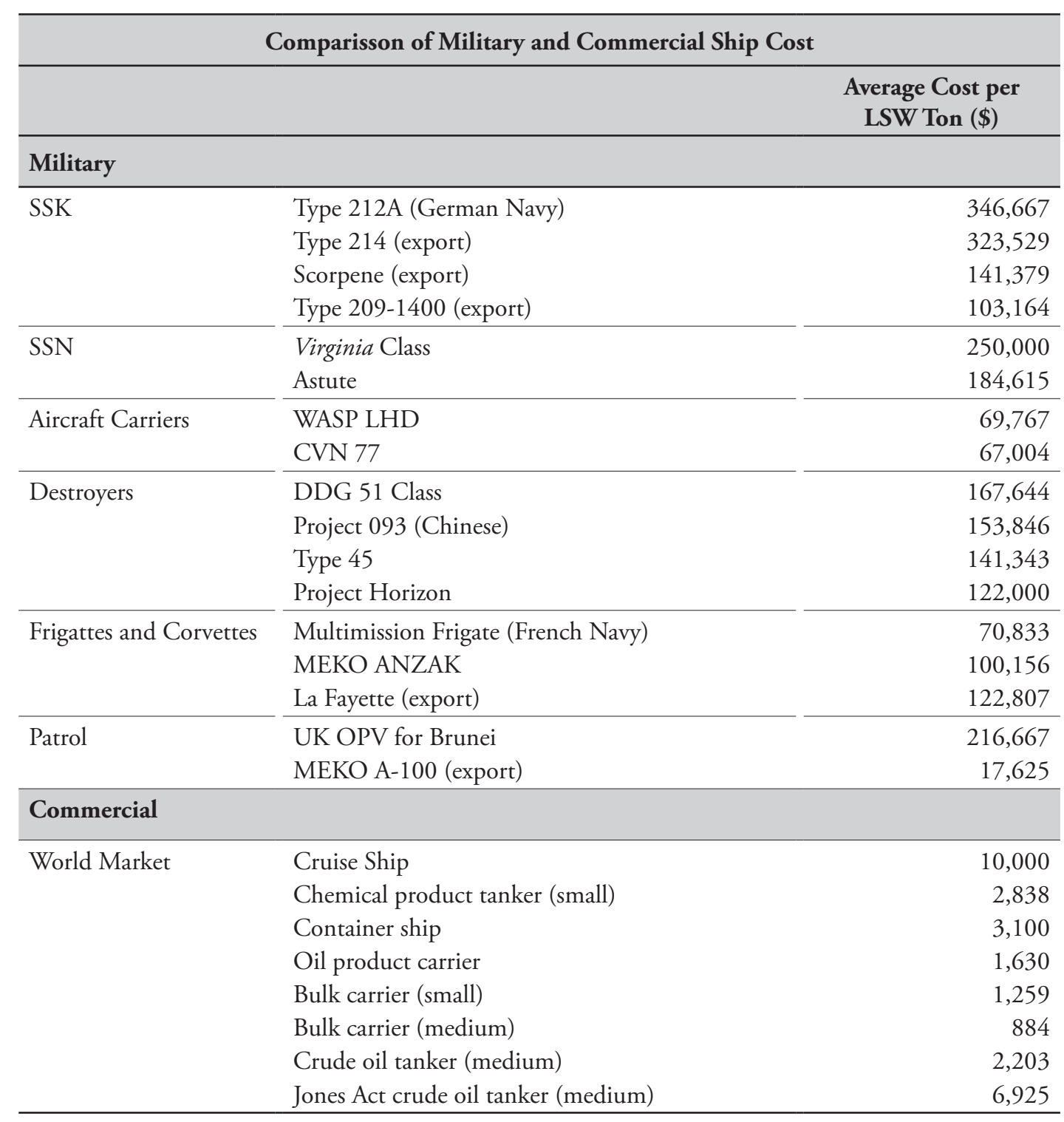

Source: Birkler et al., 2005

Fig. 1. FREM Frigate

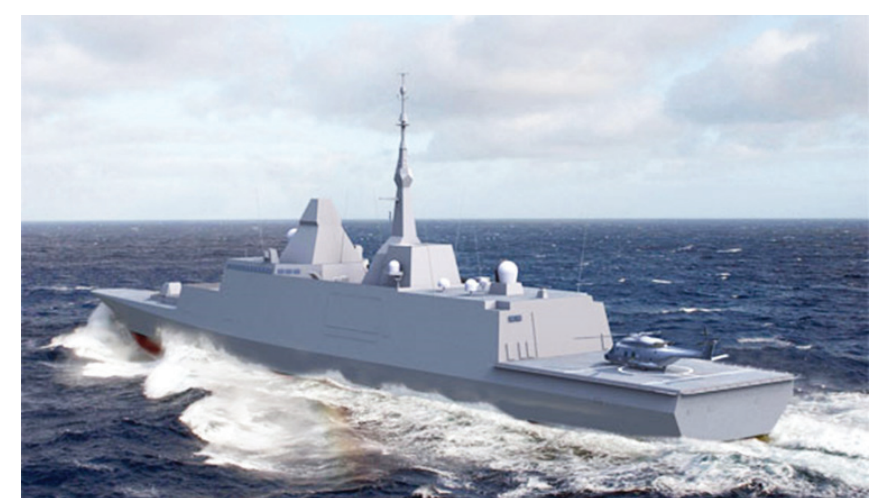


Fig. 2. British Type 26 Frigate

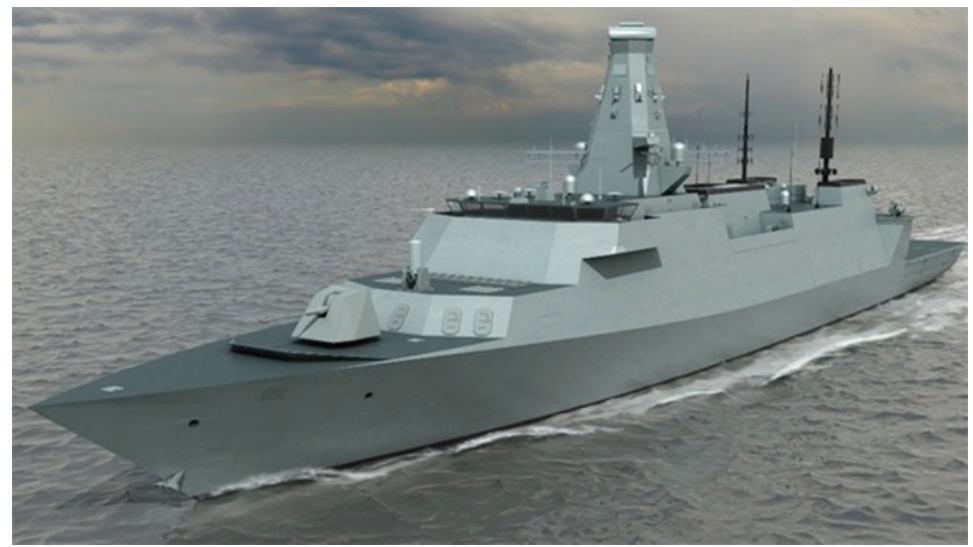

Many countries that want to build their own naval ships do so in the hope of establishing a shipbuilding industry within their country. They may already have a commercial shipbuilding capability or part of their plan may be to use the naval shipbuilding program (paid by the government) to jump start a commercial shipbuilding long term capability. Unfortunately, in both cases, this has not been too successful.

Some countries that have a reasonable commercial shipbuilding capability assume that this can be transferred to naval shipbuilding. Unfortunately, history has proven them wrong. Even the experience of small successful shipbuilders such as those involved in the LCS program in the USA, was not enough to enable them a successful transition into naval shipbuilding. That program ended up with the first ship costing over three times the original budget and twice as long to build. This is not a unique situation. Many naval ship design and constructions programs end up in similar straights

Part of the reasons for this is of the different skills required by the workers and the number of workers for naval ships compared to commercial. Fig. 3 shows the difference in worker skills for commercial and naval shipbuilding and Fig. 4 shows (Birkler et al., 2005) the worker man-hour breakdown for a Destroyer compared to a 75,000 t Bulk Carrier.

Fig. 3. Difference in Worker Skills for Commercial and Naval Ships

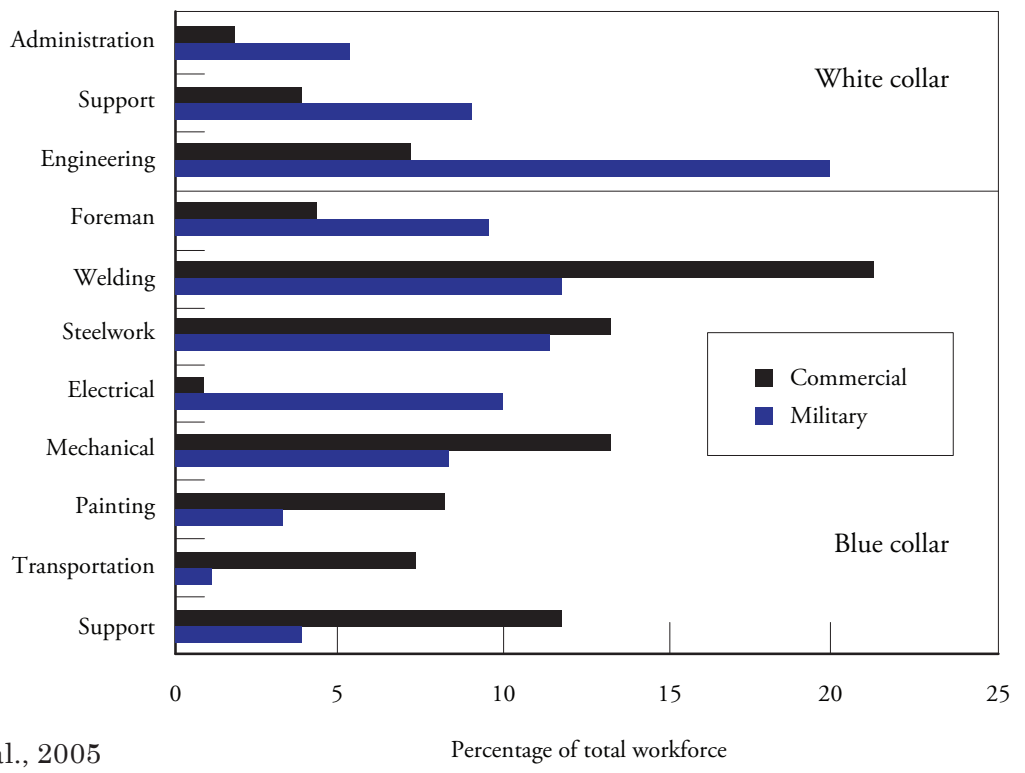


Fig. 4. Comparison of Shipbuilding Man-hours for Commercial and Naval Ships

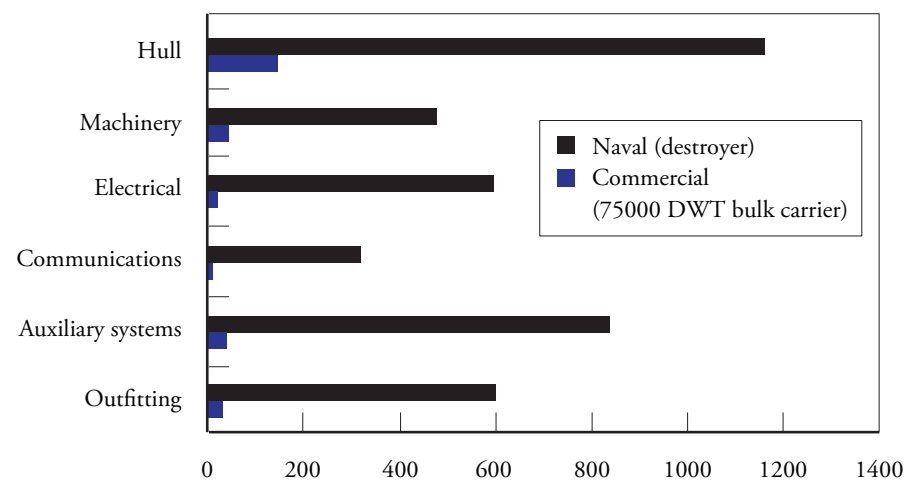

It can be seen from Figure 3 that the big differences are $250 \%$ more for design, $200 \%$ for supervision of workers and $900 \%$ for electrical. Of course this figure can be misleading in that there are a number of disciplines where the commercial shipbuilder has a greater percentage than the naval. The true manning problem is shown in Fig. 4 where in all cases the man-hours for the naval ship are many times greater (factor of 10) than that for the commercial ship.

Another significant difference is the design and building schedules between commercial and naval ships. A typical schedule for a new combatant ship from Concept Initiation to completion of Detailed Design is shown in Fig. 5. It is based on experience in the USA where the design and construction capability exists (no country designs and builds as many naval ships as the USA see Fig. 6) and even with all this experience and activity the US naval shipbuilders have problems in design and construction; technical, cost and schedule.

The actual construction time that would be added to the design timeline for the first of a new frigate would be from 3 to 5 years with some overlap (start of construction before completion of design). So the total time from concept initiation to delivery of the first frigate would range from a minimum of 10 years to a maximum of 16 years.

A review of a range of recent new frigate designs show Detailed Design time from 3 to 5 years, Contract Award to Start of Fabrication of 3 years, Start of Fabrication to Launch of 3 years and launch to delivery of also 3 years.

Compare these to commercial ship design schedules of 6 to 12 months and build schedules from 6 to 9 months.

Fig. 5. Typical US Naval Ship Design Timeline

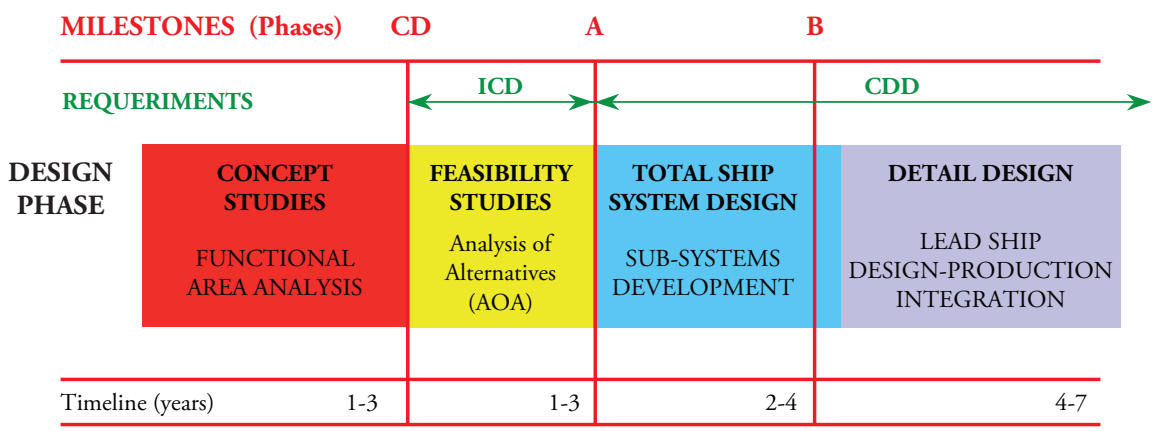


Fig. 6. Recent USA Naval Shipbuilding Programs

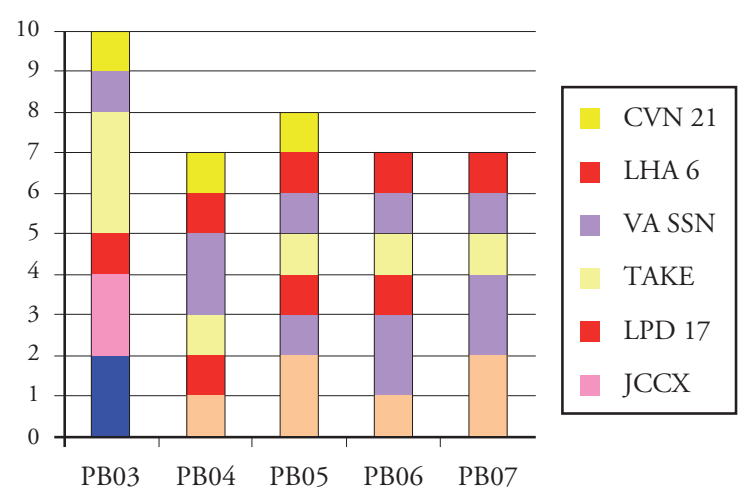

The recent accomplishment of the Danish Royal Navy and Odense Steel Shipyard is a unique and new approach. Fig. 8 shows what they were able to accomplish for the new frigate size ships of the ABSALON Class and the follow on frigate program of three ships. This was truly unique in that the build time was only a third of other programs and what is more interesting they were able to do so for $75 \%$ of the traditional frigate cost (\$330M instead of $\$ 440 \mathrm{M})$.

Fig. 7. Danish Naval Construction by Commercial Shipyard
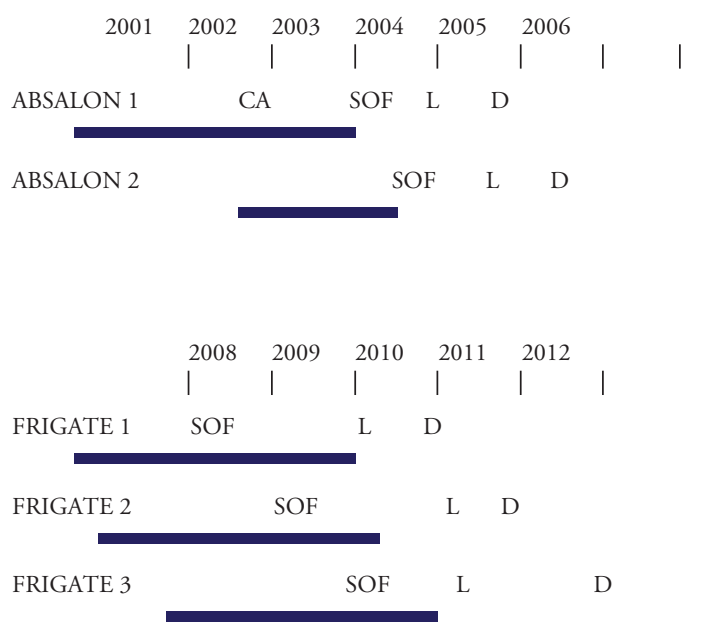

Colombia is a special situation in that it has been building military ships (small) for almost a decade. Because of shipbuilding's importance it has been defined as a strategic sector by the Ministry of Commerce, Industry and Tourism as part of their Productive Transformation Program.
COTECMAR has built complex OPVs but it needs to continue to develop intermediate projects of increasing complexity in-house to acquire the capability to design and build their own frigate.

Experience has shown that it is not easy to enter shipbuilding for the first time or re-enter after a long absence. The recent Brazilian experience is an unfortunate example of this though it was for commercial ships

So now the stage is set to look at the specific focus of this paper. The rest of this presentation will look at the challenges and opportunities that each approach has in the goal to acquire a frigate in 10 years.

\section{Challenges}

For a country that has never designed or constructed a naval combatant ship (or a country that has but it is over 25 years since they designed and constructed the last one) the first and greatest challenge is to decide on the approach.

\section{Approaches 1 and 2}

The only difference between Approaches 1 and 2 are that for 1 a new design is required whereas for 2 the objective is to find a frigate already designed and constructed. As there is no in-country design or construction involved in these approaches the challenges are minimum. Though option 2 has more risk as the desired ship has not been designed and constructed. The decision making is entirely under the control of the Navy operators. An acquisition team will probably be formed and their responsibilities are to develop the design requirements based on operational needs, develop a performance specification in the case of a new design or in the case of selecting an existing design review frigate shipbuilders products and end up with a list of the two or three that meet their requirements probably involving visits to the selected frigates in service or under construction. Then with the Navy administration, budget control and contractual groups, negotiate with the short list of shipbuilders and eventually select 
the winning shipyard. This will obviously involve the cost, build duration, delivery schedule, shipbuilder's reputation, and any political factors. Approach 2 offers the fastest availability of the ships, lowest program cost and risk. Approach 1 will take longer, involve more risk and cost more than Approach 2. The obvious downside of both these approach are that they do not do anything for the development of an eventual self-sustained naval ship design and construction capability for the acquiring country.

\section{Approach 3}

The objective of this approach is to save cost and reduce risk by having the first ship constructed by experienced shipbuilder. This approach has been used by a number of countries that wanted to use the program (especially submarines) to build up their own capability to build such ships. The challenge for the new design and construction is for it to be successfully executed and the construction documents well prepared for the follow on ships. For using an existing design the challenge is that the existing construction drawings and documents are understandable to the in-country shipbuilder without needing any rework or additional documents just to suit the in-country shipbuilder, which would add cost and extend the schedule.

\section{Approach 4}

Here the objective is to save time by not designing the ship and reduce technical risk in that the design has been proven by construction and operation. It eliminates the need to build up a large technical capability. The challenge is to build up the workers in numbers and skills to execute the construction program and avoid the undesirable experience of other similar programs in having significant cost over-run and schedule delay.

\section{Approach 5}

The challenges of this approach are:

- how to obtain required technology?
- how to build up to the required technical manning level (150 to100 for 4 to 7 years respectively)?

- how to build up to the required worker level (300 for 7 years assuming a 4 ship program)?

- what level of infrastructure should be developed within the country?

- what are the responsibilities for government, academia and industry?

- what to do with the designers and workers AFTER the program is complete?

This approach also has the highest technical, cost and delay risks. Even though the final outcome may achieve country's shipbuilding capability goal, experience with this approach has not been good.

\section{How to obtain required technology?}

This may actually be the easiest of the listed challenges to meet. There are volumes of conference transactions and other technical forums that cover most of the technology required to design a state of the art frigate. In addition there is significant information and data available on the internet. One of my favorites is http://warships1discussionboards. yuku.com/topic/21599/Majestic-class-frigate\#. URwucFbTncu. There are Naval Ship Design and Equipment Conferences held regularly in Europe and Asia. THERE IS NO NEED TO REINVENT THE WHEEL, but it is necessary to focus on acquiring the required key technologies required to achieve the country's desired capabilities. The challenge is not to find the technology but how to have new designers absorb it and mold it into an integrated ship design. This takes time and experience to be able to use it to design a successful ship.

The examples of the National Shipbuilding Research Program in the USA and the Japanese Shipbuilders Association are worthwhile examining and adapting to the new shipbuilding country's needs. Also all of the NSRP reports are available to non-US shipbuilders for a modest copying charge. Finally, the papers presented to maritime professional societies at meetings and 
conferences are well documented and available to all at a cost.

\section{How to build up to the required technical} manning level?

Many countries with a limited shipbuilding industry obtain the technical personnel by sending people to universities in countries recognized as being significant shipbuilders. Universities such as MIT and Michigan in the USA and Glasgow and Newcastle in Britain and a number in Europe are well known for their acceptance of foreign graduates. This approach enables the developing country to obtain a minimum level of knowledge at reasonable cost and in a timely manner.

The next step is to open naval architecture and marine engineering programs at existing universities. However this takes time (at least three learning cycles) before it has any impact on the country's ship design capability. Select graduates from the BS level are then sent to various universities around the world for graduate study. After graduation these Master degree graduates can fill the leadership role back home. Then the natural tendency is to start basic research and offer advanced degree programs. The problem with this approach is that it ignores the real immediate and near term need. When a country enters or re-enters shipbuilding there is little need for incountry developed research but rather for educated production oriented designers, production planners, supervisors and managers. Therefore the challenge is for higher education institutions to resist the move to emulate foreign universities offering all three levels of degrees and to focus on the immediate and short term need for the new shipbuilding industry and to assist the shipbuilding industry by providing access to the required key technologies (a transfer of technology) that will support the shipbuilders needs.

Another approach is to send both design and production employees to a foreign shipbuilder to serve an apprenticeship for at least 3 years. The disadvantage of this is that their labor contribution is lost for this time but it is one of the surest and fastest ways to achieve the required knowledge and experience.

\section{How to build up to the required worker level?} The development of the required worker skills must be developed in-country. If there are enough shipyards and time it can be done by the regular apprenticeship approach. However, to reach the manning level required for a 4 ship frigate program would take 10 years.

What is needed is a different and faster approach. The involvement of shipbuilding training should start in the high schools and continue in vocational colleges and then shortened apprenticeships at the shipyards. The challenge here is where to find the lecturers/trainers for such a program?

\section{What level of infrastructure should be developed within the country?}

Shipbuilding is an assembly industry where some of the components are fabricated in the shipyard and the remainder purchased. For commercial ships the proportion of purchased material and equipment is $60 \%$. For naval ships it is even greater with the weapons and their control systems. When a country enters or re-enters shipbuilding the incountry infrastructure does not exist and there is no choice but to utilize foreign sources. Often a country undertaking such an approach is doing so for social and political reasons and may invoke that a certain proportion of the manufacture of required components be done by new in-country small businesses. Typical "packaged" systems obtained from foreign sources are propulsion, war fighting including weapons, and electronics.

The decision on infrastructure should be part of an integrated National Shipbuilding Program. It should involve the development of a national awareness of the maritime world and its current and potential impact on the country. In some cases countries dictated that for major components, such as propulsion engines, the selected foreign engine manufacturer must set up manufacturing capability in the acquiring country.

\section{What are the responsibilities for government,} academia and industry?

The most important part of any plan involving the expansion of any industry within a country and a major success factor is how well the various 
government, academic and industry players work together and also how they approach the shared responsibilities. The government must provide the overall goal for the long term plan, any funding that is required for government, academia and industry, removal of traditional obstacles, the building of a maritime interest and support by the public, programs to schools fostering the marine industry. The government should establish trade agreements with the countries that the industry needs to purchase material and equipment from. The government should also provide long term marketing at government level so the foreign competition is fair and thus future ship contracts can be won. It is also the government's responsibility to monitor that the academia is providing the number and capability of graduates to support the plan. Academia has the responsibility to provide industry with the graduates they need to meet the plan. They must be open to immediate and short term basic and practical needs and not set up programs that produce well educated theorists that do not know how to build ships. What industry needs in its early development are graduates that can design ships and manage their construction. Finally, industry must work with the government and

together establish a realistic approach to meeting the national plan, setting of milestones so that the plan can be monitored and changes made if necessary to support ultimate goal. Obviously it is the responsibility of industry to determine the numbers of designers, managers and workers needed to execute the immediate and long term program and to apply a growth plan for their shipyards (academia would use the projected numbers and needs to develop supporting programs). Industry must also design the ships and construct them

What to do with the designers and workers AFTER the program is complete?

This is perhaps one of the biggest challenges but is often ignored in the vain hope that somehow something else will come along to maintain the new shipbuilding capability after the naval ship program is completed. This must be planned for. The usual plan is that the capability built up by the naval ship program can immediately allow the country to enter the international shipbuilding market. Unfortunately that often does not occur because of the differences between commercial and naval ship design and construction mentioned above.

\section{Opportunities}

\section{Approach 1}

The advantage of this approach over Approach 1 is that it offers the county's Navy the opportunity to determine and define, in a Performance Specification, the exact requirements that it needs in the frigate for its planned operations. There would be a limited opportunity for the Navy's technical staff to learn some ship design and construction techniques from the overview of the foreign shipbuilders design and construction activities.

\section{Approach 2}

This approach offers little opportunity to improve a country's own ship design and construction. It would offer the Navy to gain experience with state of the art frigate operations and thus the potential to better define its requirements for future naval ships.

\section{Approach 3}

The process of selecting an existing ship design will offer opportunities to learn from the review process and an evaluation of the construction approach will give reviewing team some shipbuilding knowledge. It is likely that once the selection is made, technical, management and some workers will be station in the shipyard during the construction of the first ship and they will lead the technology transfer and detailed building plans to their shipyard for the construction of follow-on ships. This approach only offers limited opportunity for technology 
transfer and mostly the opportunity to develop the ship construction process. By not starting construction until the building of the first ship is completed offers the opportunity not to avoid the problems of starting before the design is mature ( $>80 \%$ complete). This is a widely recognized productivity problem for many past new programs. Thus after completion of the frigate program it would offer a ship construction capability to construct complex ships from existing designs.

\section{Approach 4}

Here again the focus is on the ship construction capability improvement not the ship design. If an existing design is selected it would reduce cost and time before starting construction. Thus the opportunity is to get the first ship faster than if it is a new design. If it is an existing design that has been constructed the risk of starting the construction immediately is small. If a new design is obtained from a foreign ship designer all the risk of taking care of initial ship design problems remain and this is coupled with the usual first ship construction problems in the country's shipyard(s). If it is a new design there is the opportunity of the originating country to form a joint development and construction program with other countries, such as the FREM program.

\section{Approach 5}

This approach offers the greatest improvement opportunities for a country desiring to enter the shipbuilding industry, but with the greatest technology, cost and schedule risk. The opportunities are many and varied and would have the greatest and broadest benefit to the country's supporting institutions and other industries.

From the cost aspect, if the acquiring labor rate is significantly lower (say 1/3) than existing naval shipbuilders labor rate then there is a potential of $45 \%$ saving in labor cost or $25 \%$ of total ship cost. This would NOT be achieved for the first or second ships but for the follow on ships.

From the technology aspect it offers the exact matching of defined Navy requirements. This would include examining the suitability of unique hull forms such as Trimarans (Fig. 8) and SWATH (Fig. 9) forms that traditional countries seem reluctant to use (except for USA LCS 2 and the recently reported new Indian frigate program).

It also offer the opportunity to use the latest and better ship design tools than were probably used for an existing design. By designing incountry it will give the design staff as well as the education institutions the opportunity to obtain the latest design systems such as the British PARAMARINE (Fig. 10). This allows the ship to be designed from the inside out rather than to fit the required spaces into a pre-established hull form.

This approach would give great opportunity to all levels of education to establish a program that would meet the shipbuilding industry's needs. The opportunity at the university level must be focused on the needs of the next 10 years and not to copy existing universities with long histories of advanced teaching. The need in the next 10 years is for graduates that can help move from a non-existent or small ship design and shipbuilding capability to one that can design and construct modern ships, both naval and commercial. This does not need a lot of research. The need for research will grow as the long term shipbuilding industry grows. The warning given above is repeated here: THERE IS NO NEED TO REINVENT THE WHEEL.

A great opportunity exists for the schools and vocational colleges. The schools must promote the maritime world to its pupils and thus generate an interest in it. The vocational colleges must develop programs that provide the beginning of the training process for future shipbuilders. 
Fig. 8. LCS 2 Trimaran

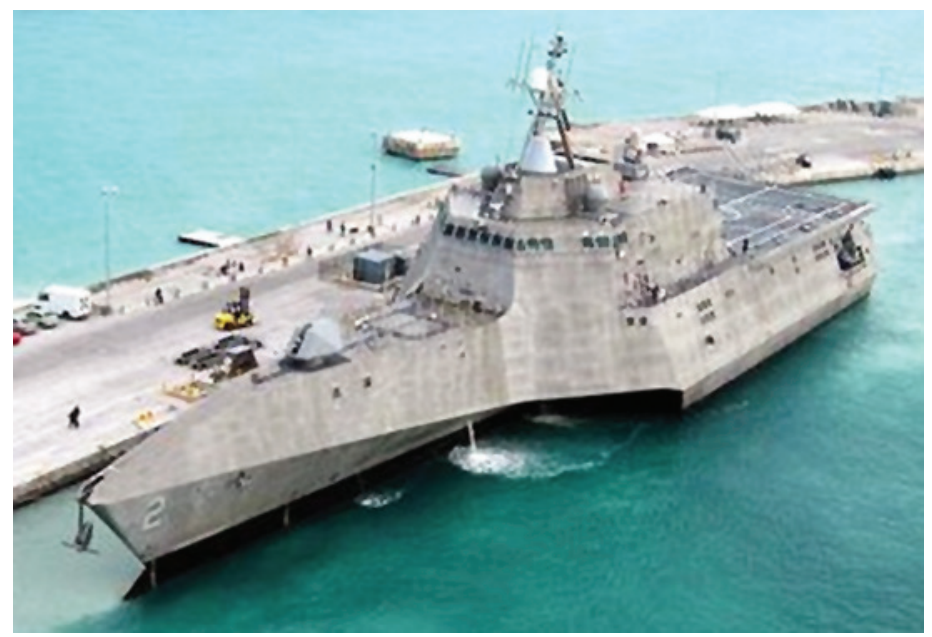

Fig. 9. SWATH Hull Forms
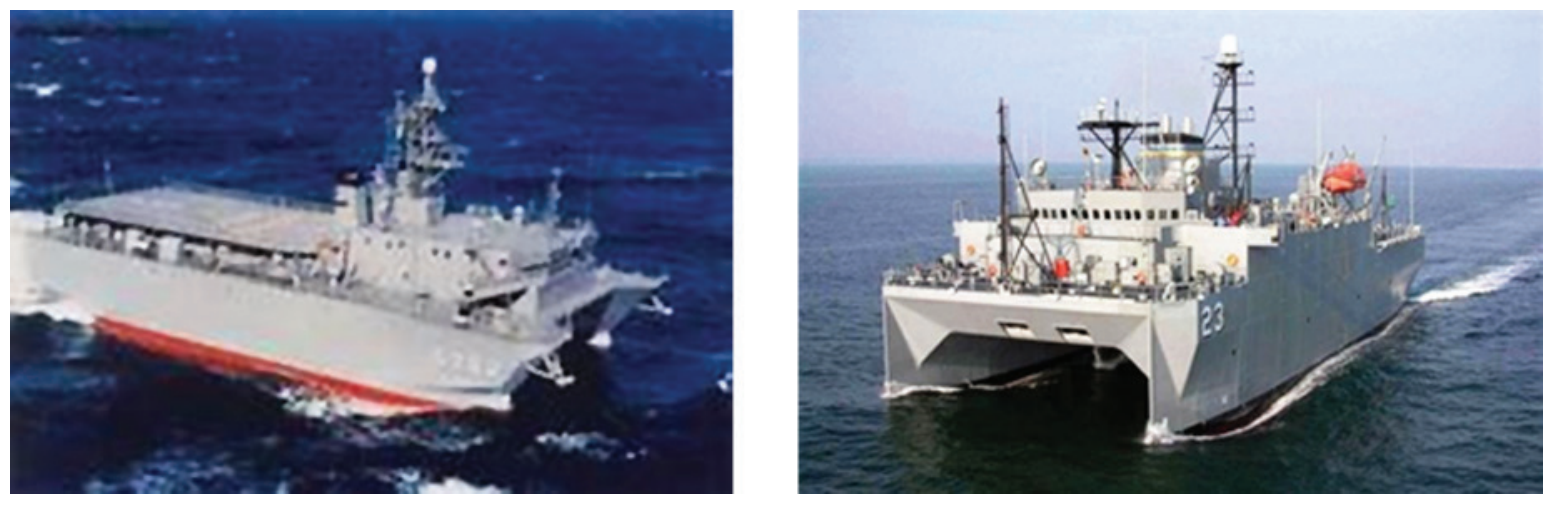

Fig. 10. Paramarine Frigate Design

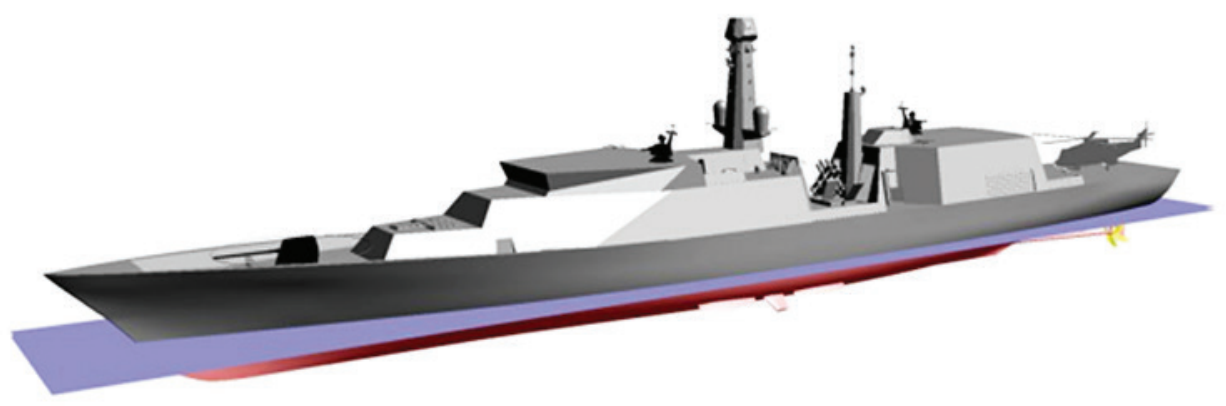

\section{Conclusions}

Five different approaches for acquiring naval ships have been presented and the challenges and opportunities discussed with a focus on a frigate. They are summarized in Table III. However, only the technical issues have been discussed in the presentation. 
Table 3. Ship acquisition source approach summary

\begin{tabular}{|c|c|c|c|c|}
\hline Approach & Description & Challenges & Opportunities & Risk \\
\hline 1 & $\begin{array}{l}\text { Complete Purchase } \\
\text { New Design }\end{array}$ & $\begin{array}{l}\text { Normal new program } \\
\text { for foreign shipbuilder }\end{array}$ & $\begin{array}{l}\text { None for acquiring country not } \\
\text { even technology transfer }\end{array}$ & $\begin{array}{l}\text { Next } \\
\text { Lowest }\end{array}$ \\
\hline 2 & $\begin{array}{l}\text { Complete Purchase } \\
\text { Existing Design }\end{array}$ & $\begin{array}{l}\text { Design may not meet } \\
\text { requirements and thus } \\
\text { need significant change }\end{array}$ & $\begin{array}{l}\text { Same as } 1 \text { but fastest acquisition } \\
\text { of ships }\end{array}$ & Lowest \\
\hline 3 & $\begin{array}{l}\text { Foreign Design and } \\
\text { First Ship Build }\end{array}$ & $\begin{array}{l}\text { How to develop workers } \\
\text { with the required skills }\end{array}$ & $\begin{array}{l}\text { Saving in total cost IF acquiring } \\
\text { country's labor rate is significantly } \\
\text { lower than experienced } \\
\text { shipbuilder rate. } \\
\text { Learning in foreign shipyard and } \\
\text { time to buildup own work force }\end{array}$ & Medium \\
\hline 4 & $\begin{array}{l}\text { Foreign existing or } \\
\text { new Design } \\
\text { Self-Build }\end{array}$ & $\begin{array}{l}\text { How to overcome lack } \\
\text { of experienced and } \\
\text { skilled workers }\end{array}$ & $\begin{array}{l}\text { Saving in total cost IF acquiring } \\
\text { country's labor rate is significantly } \\
\text { lower than experienced } \\
\text { shipbuilder rate. } \\
\text { Long term development of } \\
\text { shipbuilding capability }\end{array}$ & High \\
\hline 5 & $\begin{array}{l}\text { Self-Design Self- } \\
\text { Build }\end{array}$ & $\begin{array}{l}\text { Significant } \\
\text { All challenges discussed }\end{array}$ & $\begin{array}{l}\text { Saving in total cost IF acquiring } \\
\text { country's labor rate is significantly } \\
\text { lower than experienced } \\
\text { shipbuilder rate. } \\
\text { To join with other countries } \\
\text { who need naval ship to share } \\
\text { development cost and provide } \\
\text { more resources. } \\
\text { Long term development of } \\
\text { shipbuilding capability }\end{array}$ & Highest \\
\hline
\end{tabular}

The important social and political factors have not and it is possible that they will be the deciding factors. The social and political factors include:

- building up technical level,

- expansion of university and technical college attendance

- providing industrial work to improve unemployment,

- generating more tax revenues, and

- reducing outflow of money for the project thus reducing the imbalance of payments.

From the cost aspect, if the acquiring labor rate is significantly lower (say 1/3) than existing naval shipbuilders' labor rate then there is a potential of $45 \%$ saving in labor cost or $25 \%$ of total ship cost. This would NOT be achieved for the first or second ships but for the follow on ships. This is a significant reason for building the naval ship in the acquiring county.

The preparing of a new ship design and engineering by the acquiring country designers offers the greatest long term capability generating opportunity but it also is a high risk approach.

Approach \#4 offers the best compromise in that it has the lowest design risk (even if extensive changes are made to arrangements and weapons) and it offers the best potential for improving the acquiring country's shipbuilding capability. However, the introduction of politics will affect the final choice. 
If the political goal is to establish a long term shipbuilding capability in the country then it is essential that a National Shipbuilding Policy be established covering not only the frigate program but for ships both commercial and naval beyond that, including the education of professionals both technical and management, the training of workers, the required infrastructure, financing programs, etc. its successful outcome depends on how well the plan is organized and how well all the players; government, academic and industry, work together.

So whatever approach is selected the challenges associated with that approach must be understood and actions taken to alleviate their adverse impact on the program and the opportunities that best fit with the selected approach must be put into action. The approach must be based on a broader longer term plan; it cannot be based only on a few frigates. It must include programs parallel to and after the frigates that can sustain the resulting capability and the level of designers and workers. That is the plan must balance the capability developed for the frigates with the long term shipbuilding strategy. Then stick with the decision. Follow the well-known dictum: PLAN THE WORK, WORK THE PLAN.

The presentation has deliberately been generic in that the contents apply to any country and naval combatant ship. In this conclusion I would like to end by focusing on Colombia. How does it all affect Colombia? Fortunately Colombia is NOT just entering shipbuilding. In COTECMAR it has a shipbuilding capability that has been built up over the past decade. Throughout this time it has focused on having a strong design and development capability which has tackled more complex ships such as the OPVs and continually improved its knowledge in ship design and shipbuilding processes.

It also has universities that offer naval architecture education and is currently implementing advanced graduate studies. Over the past few years Colombia has developed a national Product Transformation Program of which shipbuilding has been recognized as a strategic sector.
All this obviously reduces the challenges and thus risks discussed above, but there is still a level of challenges and many opportunities for the country in expanding the shipbuilding capability and all the related support that goes with this such as university education and worker training.

\section{Bibliography}

BIRKLER, J. RUSHWORTH, D. CHIESA, J PUNG, H. ARENA, MARK V. SCHANK, JOHN F. Differences between Military and Commercial Shipbuilding. Implications for the United Kingdom's Ministry of Defence. RAND Corporation. 2005.

$\begin{array}{llr}\text { FORECAST INTERNATIONAL } & \text { NAVAL } \\ \text { GROUP. 'Warships Forecast'. } & \text { Forecast } \\ \text { International/DMS. March 2003. } & \text { www. } \\ \text { forecast1.com } & & \end{array}$

